\title{
Leadership Style and the Internal Processes in Communities of Practices
}

\author{
Chao-Hua Li ${ }^{1, *}$, Kun-Shan $\mathrm{Su}^{2,3}$, Shu-Fen Liu ${ }^{4}$ \\ ${ }^{1}$ Department of Business Administration, TransWorld University, Taiwan \\ ${ }^{2}$ St. Joseph's Hospital, Taiwan \\ ${ }^{3}$ Chu Shang Show Chwan Hospital, Taiwan \\ ${ }^{4}$ Department of Business Administration, TransWorld University, Taiwan
}

Copyright $(\mathcal{C} 2015$ by authors, all rights reserved. Authors agree that this article remains permanently open access under the terms of the Creative Commons Attribution License 4.0 International License

\begin{abstract}
Communities of Practices (CoPs) become building blocks of the knowledge economy. CoPs offer a productive solution for improving knowledge and knowledge management. This article presents the results of an empirical study that explored the impact of leadership on overall community effectiveness and knowledge creation and management. The research method employed was a multi-case study, with purposive sampling on two communities of Radiology and Anesthesia in a nonprofit healthcare organization of Taiwan. A total of 24 semi-structured interviews were taken with longitudinal non-participant observation of the routine meetings over a period of one year. The research revealed that two communities develop different leadership styles. In particular, two leadership styles are compared: shared leadership and single leadership. Shared leadership represents communities whose members are empowered to share the tasks and responsibilities of leadership. The results of the study suggest that $\mathrm{CoP}$ with shared leadership can nurture $\mathrm{CoP}$ to promote innovative learning and knowledge-sharing environment. First, shared leadership is capable of building a social setting for utilizing and articulating individuals and groups' embedded knowledge. Second, shared leadership can work together on setting learning support system entailing various types of meeting, such as regular meeting, morning meeting, and monthly meeting, make environmental influence on individual' motivation to engage in CoPs. Third, the sharing norms purposely developed by leadership overcome the power differences among members and provide chances for constructive interactions. On the other hand, a CoP that took the traditional approach of relying on a single leader has poor performance on the cohesiveness and ability to communicate. The article concludes with a discussion of some guidance for purposeful design of $\mathrm{CoPs}$, implications, and future research opportunities.
\end{abstract}

Keywords Communities of Practices, Shared (Distributive) Leadership, Knowledge Creation

\section{Introduction}

The knowledge-based view of the firm sees knowledge as a factor to explain the idiosyncrasies of firms (e.g., von Krogh et al. 1994, Spender and Grant 1996). Winter (1987) argues that tacit knowledge is a source of competitive advantage for firms. This work triggered subsequent research on knowledge in organization. Among organizational knowledge theory, the social practice view of the organizational knowledge (e.g. Wenger 1998; Brown and Duguid 1991, 2000) analyzed existing, tightly-knit groups operating in socially stable organizational contexts that allow individuals to acquire tacit knowledge through socialization in practice. Communities of Practices (CoPs) are the nexus for sharing and transferring of valuable tacit knowledge possessed by individuals and groups (Kogut and Zander, 1992). The purpose of this paper is to explore the role of leadership in facilitating the development of CoP. The paper is structured as follows. First, a review on $\mathrm{CoP}$ is provided. This includes a discussion on how the facilitators in the social context that nourishes the willingness to engage in the (joint) effort to build and maintain the CoPs, including the role of leadership on the function of knowledge sharing and transfer. Second, the research framework and methodology are discussed. Third, key research findings are discussed. This section also highlights the key success factors that contributed to nurturing CoPs. Finally, the paper concludes with some implications and suggestion for future research.

\section{Literature Review}

The research of CoPs has focused on a processual, interaction-based conception of organizational knowledge (Brown \& Duguid, 1991, 2000; Orlikowski, 2002). CoP theory in knowledge management seeks "a perspective that 
focuses on the knowledgeability of action, that is on knowing (a verb connoting action, doing, practice) rather than knowledge (a noun connoting things, elements, processes, disposition)" (Orlikowski, 2002, p.251).The most comprehensive analysis of the internal dimensions and processes of CoPs to date comes from Wenger (1998). The three elements-mutual engagement, shared repertoire, and negotiation of a joint enterprise constitute mechanisms to determine knowledge dynamics and to explore further the process of knowledge creation in CoPs. CoP theory strongly emphasizes the interactively constructed nature of engaging, sharing, and negotiating. The dynamic, procesual focus on practices makes $\mathrm{CoP}$ theory a situated framework for analyzing the dynamic process in knowledge creation through the communicative acts of the three elements (Iverson and McPhee, 2008). Thus, CoP theory offers a schema for analyzing knowledge as a process.

The learning approach in CoPs reflects a sociocogntive perspective which points that it is this social context that nourishes the willingness to engage in the (joint) effort to build and maintain mutually shared cognition (Barron, 2003; Crook, 1998). Van den Bossche et al. (2006) suggested that five constructs, social interdependence, social cohesion, task cohesion, group potency and psychological safety constitute the social conditions under which teams make the effort to reach shared knowledge. A CoP emphasizes sharing new knowledge and product that emerge over time with the broader community and the field at large. Therefore, practices that manage the co-construction of mutually shared cognition (or a shared repertoire) and conditions in the interpersonal context contribute to engagement in these knowledge-building practices

Table 1. Indicators that a community of practice has formed

\begin{tabular}{|c|c|}
\hline Dimension & Indicators of a community of practice \\
\hline $\begin{array}{c}\text { Mutual } \\
\text { engagement }\end{array}$ & $\begin{array}{l}\text { 1) Sustained mutual relationships - harmonious or } \\
\text { conflicting. } \\
\text { 2) Shared ways of engaging in doing things together. } \\
\text { 3) The rapid flow of information and propagation of } \\
\text { innovation. } \\
\text { 4) Absence of introductory preambles, as if } \\
\text { conversations and interactions were merely the } \\
\text { continuation of an ongoing process. } \\
\text { 5) Very quick setup of a problem to be discussed. }\end{array}$ \\
\hline $\begin{array}{c}\text { Joint } \\
\text { enterprise }\end{array}$ & $\begin{array}{l}\text { 6) Substantial overlap in participants' descriptions of } \\
\text { who belongs. } \\
\text { 7) Knowing what others know, what they can do and } \\
\text { how they can contribute to an enterprise. } \\
\text { 8) Mutually defining identities. } \\
\text { 9) The ability to assess the appropriateness of actions } \\
\text { and products }\end{array}$ \\
\hline $\begin{array}{l}\text { Shared } \\
\text { repertoire }\end{array}$ & $\begin{array}{l}\text { 10) Specific tools, representations and other artifacts. } \\
\text { 11) Local lore, shared stories, inside jokes, knowing } \\
\text { laughter. } \\
\text { 12) Jargon and shortcuts to communication as well as } \\
\text { the ease of producing new ones. } \\
\text { 13) Certain styles recognized as displaying } \\
\text { membership. } \\
\text { 14) A shared discourse reflecting a certain perspective } \\
\text { on the world. }\end{array}$ \\
\hline
\end{tabular}

Source: Adapted from Wenger (1998:125-126)

\subsection{The Three Elemental Processes of CoPs}

The core of CoP theory: mutual engagement, shared repertoire, and negotiation of a joint enterprise is summarized as the three elemental processes of CoPs. Wenger provides empirical indicators of the existence of a community of practice. These indicators can be classified as specific manifestations of the defining dimensions, as shown in Table 1. These indicators provide coherent criteria for evaluating communities of practice studies and detecting lack of rigor about a CoP.

\subsection{Leadership and Communities of Practices}

Wenger (1998, p.74) suggests that members of a CoP "sustain dense relations of mutual engagement organized around what they are there to do." The community needs to set up the mechanisms of engagement for members to socialize with one another so that there is adequate engagement to sustain the process of a CoP. In knowledge management, the environment is called 'ba', defined as "a shared context in which knowledge is shared, created and utilized (Nonaka, et al. 2000)."A community leader has the skills to motivate people to interact with each other and the leader makes impact on interaction quality (Zboralski, 2009). A community leader in terms of a facilitator is the critical contextual success factors of CoP. A community leader can act as a facilitator, i.e.an enabler for trust, cohesion and a positive communication climate within the CoP.

Thus, the better a community leader regulates the interaction frequency, the more information exchange flows will be. The more information exchange flows are, the boundary of belonging becomes clearer. From the perspective of social learning process, personal engagement provides opportunities to an individual to learn by observation, imitation, and modeling (Bandura, 2001). Managers can create an environment that provides opportunities for observing appropriate behaviors and one that supports and encourages modeling and imitation. Successful mutual engagement offers a context for socialization. In socialization, individuals can capture the full range of physical senses and psycho-emotional reactions, such as ease of discomfort, which are important elements in sharing tacit knowledge (Nonaka, et al. 2000). A community leader creates a work environment that allows peers to understand tacit knowledge embedded in the community. Tacit knowledge such as mental models, mutual trust, and commitment can be created and shared.

\section{Research Methods}

\subsection{Selection of the Case}

This study chooses a nonprofit organization, located in Yunlin of Taiwan. The organization is St. Joseph's Hospital. Established by Bishop Thomas Niu of the Chiayi diocese in 
1955, St. Joseph's Hospital had its initial 15 beds; currently, it has a scale of 499 beds. Strategically, this hospital serves the 800000 population of Yunlin; nevertheless, its aims are to provide complete medical services to the residents, especially the poor, of Huwei and its neighboring towns. In the early times, the hospital did not have sufficient specialist physicians and nurses, who mostly saw patients of all types of disease. Today, the entire outpatient treatment services cover a total of 18 clinical specialties and subspecialties including internal medicine, surgical and other clinical departments. On the average, the hospital receives as many as 1,300 outpatients each day. Approximately, the hospital has more than one hundred physicians and two hundred nurses.

A nonprofit organization differs from a profit enterprise in the motive of managing a business. A nonprofit organization is operated for charity while the profit motive creates economic conscription to the organization. CoPs cannot be managed but must be nurtured and cultivated, and groups or working units in St Joseph's Hospital. As a result, such a background may nurture a type of organizational culture that allows empowerment. This study aims to analyze groups of professions in Anesthesia Department, and the X-Ray Department. Members in Anesthesia Department, and the $\mathrm{X}$-Ray Department are medical technicians under a doctor's leadership. Doctors in the two departments have considerable professional autonomy in managing a CoP. There are similar characteristics in the background, so each of the two departments can be a comparison group to each other (Janesick, 2000).

\subsection{Data Collection and Analysis}

Table 2. the Profile of Interviewees

\begin{tabular}{|c|c|}
\hline Department of Radiology & Anesthesia Department \\
\hline Title, Name, Sex, Length of Working & $\begin{array}{c}\text { Title, Name, Sex, Length of } \\
\text { Working }\end{array}$ \\
\hline Supervisor, Miss Hwang,(F), 10 years & $\begin{array}{l}\text { The head of nurse, Miss Lin, } \\
\text { (F), } 16 \text { years }\end{array}$ \\
\hline Radiologist Hwang, $(\mathrm{F}), 10$ years & Nurse Lin, $(F), 19$ years \\
\hline Radiologist Tsai, (M), 8 years & Nurse Lin, $(F), 15$ years \\
\hline Radiologist Hsu, $(\mathrm{F}), 8$ years & Nurse Lee, $(\mathrm{F}), 10$ years \\
\hline Radiologist Fang, (M), 7 years & Nurse Lin, $(\mathrm{F}), 10$ years \\
\hline Radiologist Hong, $(\mathrm{F}), 5$ years & Nurse Tsai, $(\mathrm{F}), 7$ years \\
\hline Radiologist Wang, (F), 0.5 year & Nurse Cheng, $(\mathrm{F}), 5$ years \\
\hline $\begin{array}{c}\text { Radiologist Intern,(F), Miss Lin, } 1 \\
\text { year }\end{array}$ & Nurse Zhang, $(F), 3$ years \\
\hline Radiologist Kao, (F), 1 year & $\begin{array}{l}\text { Nurse Lee, }(\mathrm{F}), \text { not } \\
\text { mentioned }\end{array}$ \\
\hline Radiologist Chen, $(\mathrm{F})$, not mentioned & Nurse Yang, $(F), 10$ years \\
\hline Radiologist Chuo, (M), not mentioned & $\begin{array}{c}\text { Physician } \mathrm{Y},(\mathrm{M}), \text { not } \\
\text { mentioned }\end{array}$ \\
\hline Physician X (M), not mentioned & $\begin{array}{l}\text { Physician } \mathrm{X},(\mathrm{M}) \text {, not } \\
\text { mentioned }\end{array}$ \\
\hline
\end{tabular}

Data from two departments are planned to collect by the author, with some help from research assistants. The researchers had collaborative relationship with the doctors. Then, based on the coalition, the researchers could get insider's perspective, observing flows from the perspective of non-participating. This study made in-depth interviews on 24 members and doctors in two departments. The profile of participants is listed in Table 2

Thus, the types of data can be specified as follows: (1) the fieldwork data: regular morning meetings, on-call responses, classroom training, conversation with doctors and members, and cross-boundary meetings; (2) Semi-structured interviews, including members, and doctors; (3) Reference data: training course materials, archive in on-call responds, and meeting minutes. Interview guidelines for three elements of CoPs follow Iverson and McPhee (2008), with questions like "How much contact do you have with other working members?" "What led up to that change?" and "In what ways do you feel as though you have input into or influence on the process of the medical job?"

This research applied NVIVO 8.0 to analyze transcripts. The analysis approach is a series of highly structured steps. It involves the systematic comparison of small unit of data (events) in constantly reviewing, comparing and contrasting. Little by little, emergent differences and similarities are observed and form particular patterns within the data. Patterns may be subcategories that can be integrated connected. Several "subcategories," and associated "dimensions" and "properties," are gradually elaborated and refined as specific incidents are examined, systematically coded, and compared. The researcher deliberately seeks out data that will enable verification of the properties of emerging category systems. Eventually, the result showed that leadership style is the core category that serves to tightly integrate all the theoretical concepts into a coherent whole firmly rooted in the original evidence.

\section{Results}

The research explores the management of CoPs with leadership inside CoPs in a micro-level. The leadership is defined as internal community leaders who initiate the acts of leading and provide resources and coordination to the interactions. According to Wenger and Snyder (2000), "successful managers [can] bring the right people together, provide an infrastructure in which communities can thrive, and measure the communities' value in nontraditional ways." This research found that there were two types of leadership in the research subjects: the practice of shared leadership and the practice of single leadership. The discussion logically follows the three elements of CoPs in Wenger and Snyder (2000) and shows their connection to the leadership (see Table 3). 
Table 3. Differences between Shared Leadership and Single Leadership

\begin{tabular}{|c|c|c|}
\hline & Shared Leadership & Single Leadership \\
\hline $\begin{array}{c}\text { Mutual } \\
\text { engagement }\end{array}$ & $\begin{array}{l}\text { Director as the key } \\
\text { person to convene } \\
\text { meetings } \\
\text { each person has } \\
\text { chance to lead a } \\
\text { conversation, or to } \\
\text { introduce a new topic } \\
\text { to discuss }\end{array}$ & $\begin{array}{l}\text { - The average time } \\
\text { of meeting is once } \\
\text { a month } \\
\text { to convey } \\
\text { information } \\
\text { through the shift } \\
\text { book }\end{array}$ \\
\hline $\begin{array}{c}\text { Joint } \\
\text { Enterprise }\end{array}$ & $\begin{array}{l}\text { A system of } \\
\text { apprenticeship } \\
\text { Team goal is clarified } \\
\text { and interpreted to } \\
\text { individual cognition } \\
\text { and needs }\end{array}$ & $\begin{array}{ll}\text { To follows rules } \\
\text { in Association of } \\
\text { Radiologists } \\
\text { Each radiologist } \\
\text { has its own set of } \\
\text { standard } \\
\text { operation process } \\
\text { (SOP). } \\
\end{array}$ \\
\hline $\begin{array}{c}\text { Shared } \\
\text { Repertoire }\end{array}$ & $\begin{array}{l}\text { Relaxing surrounding } \\
\text { feeling and } \\
\text { trust-worth places are } \\
\text { supportive contexts } \\
\text { Community memory } \\
\text { is updated frequently } \\
\text { through face-to face } \\
\text { interactions }\end{array}$ & $\begin{array}{l}\text { The head of } \\
\text { radiologists is } \\
\text { responsible for } \\
\text { passing down new } \\
\text { knowledge of } \\
\text { radiologist } \\
\text { instrument. } \\
\text { Interactions are } \\
\text { not frequent, } \\
\text { mostly depending } \\
\text { on written data } \\
\end{array}$ \\
\hline
\end{tabular}

\section{Mutual Engagement}

Traditional communities of practice are to have regular face-to-face meetings, and the primary responsibility of the leader is to convene meetings, including formal and informal meetings (Fallah, 2011). The aggregate of activities encompassing knowledge sharing/creation and learningconstitute these practices. First, this research found that leadership by the director doctor set up the learning infrastructure for the members in Anesthesia Department. Every participant in Anesthesia Department expressed the director doctor's initiation in coordinating multiple communication platforms has been the basis for creating belongings and commitment to the CoP. Participants explained the benefits of daily morning meeting are to build tacit agreement, and to discuss the problems in the practice of anesthesia. Comment such as "When poor communication, both sides may have unpleasant emotions, which will affect the quality of anesthesia operation, and later we discovered that morning meeting is better than the private communication." "Through the morning we will be able to share experience, obstacles encountered and what makes you happy and moody."

In particular, it is evident that the staffs see the Director as being the key person that brings the concept of CoPs. He encourages the use of listening, brings a good book or a good article to share with you in the morning meeting. Though norms regarding attendance in meetings are not formally set up, all participants have a consensus on the importance and significant contributions made by the practices of multiple types of meeting in CoPs. One participant enthusiastically commented:

I will be able to absorb new knowledge more quickly, then it is easy to become our own stuffs, and they will not be easy to forget; actually it (the practice of CoPs) is the same as the accumulation of my experience, and then the next time you encounter the similar cases, it is less likely to be panic.

Communication between members through by reading club, weekly session and news seems to make a climate of openness of communication. And the leadership behaviors are argued to create and sustain a supportive context; comments on Director such as "My own feeling is that the physician let us talk about anything, as we meet;" "with ways to share some experiences;" "not like being instructive or focus talk."

Open conversation contributes to trust in the interaction and creates caring atmosphere. The Director has initiatives to encourage participations. Participants start conversations freely and frequently. Conversation management practiced by the Director plays a critical factor to a distributive leadership. In meetings, each person has chance to lead a conversation, or to introduce a new topic to discuss. Bolden (2011) described distributed leadership "a realization that no one individual is the ideal leader in all circumstances" and it has "given rise to a new school of leadership thought, referred to as informal, emergent, dispersed or distributed leadership". The way the meetings proceed is similar to a style of distributed leadership.

On the other hand, leadership of radiologists is rather single leadership. The higher-level director usually has little contact with the radiologists, so generally, communication between director and radiologists are going through the head of radiologists. Between the radiologists, face-to-face meeting is not much, and therefore the platform of radiologists' communication is necessary to shift to convey information through the shift book. The big difference between shared leadership and single leadership is the frequency and the amount of meetings. Our interviews with sampling and analysis of radiologists indicate that radiology meeting amount is affected by leaders. The average time of meeting is once a month when there is a need for a meeting or when there is an important policy required for advocacy. The leadership is regarded as laissez-faire leadership style.

\section{Joint Enterprise}

Wenger suggests that a CoP has an identity defined by a shared domain of interest, which is sometimes referred to as the 'domain' of the community. Wenger et al. (2002) suggest that a domain of knowledge creates a common ground for members to participate and contribute towards learning and sharing in the organization. The domain of knowledge in anesthesia department is driven intensively by safe practices of anesthesia, depending on individual patient's physical condition, such as surgery in the orthopedic patients or the impact on patients with hypertension. Nurse anesthetists explained that knowledge of anesthesia is learned mostly in working area, and it is a system of apprenticeships, that is, by anesthesiologists' 
step-by-step teaching. And when they are on duty, they need to make judgment regarding patient care on their own. A nurse anesthetist indicated the process of the interaction like:

I think work here would be more independent compared with care in other areas where you may be more fully dependent on what the doctor said. Here, for example, when encountering situations, you know that you'll be able to say immediately what to deal with such situation, as you had some experience, plus a physician will usually teach us how. But in other ward, you are more like a silly person and waiting for doctors to come; there would be more room for independent thinking.

Department of Anesthesia forms a natural CoP and creates a focus of learning on individual thinking and judgment over safe practices of anesthesia. In fact, previously, there were uneven degree of knowledge and skills in anesthesia and medical care in anesthesia was rather spotty. Some were new comers from other hospitals, or junior without experiences. Individuals dealt with issues revolving around a particular condition of patient. With the introduction of a $\mathrm{CoP}$, any problems related to a type of patient will be discussed by the members whereby expertise knowledge like pharmacology or laboratory examination, or Electrocardiography (ECG) and X-rays is checked out for further assessment and planning. The motivation for such enhanced interactions is to find a solution to problems through sharing practical knowledge and experience by different individuals in a CoP.

Our interviews indicated that a leader's role in articulating, and interpreting objectives is more effective than a group with members unmindful in their endeavors. The shared vision is to "become the most professional team Joseph Hospital" while the strategy is "to communicate, share, and to be thanksgiving to create a harmonious team of anesthesia professionals." Literature shows that leadership with shared and more process-oriented approach makes the equilibrium of command and agreement among members (Lakomski, 2008). Our interviews show that when a leader helps members to interpret and translate vision into daily work assignments, members are more capable to set their own agendas in interactions of the $\mathrm{CoP}$, and therefore potentially is informal, emergent, dispersed or distributed leadership.

On the other hand, the nature of radiology work is independence. Each member is responsible for operating the machines in a separate ward and tends to work independently. Due to chronic exposure to radiation, the nature is a high risk, and radiologists must take into account patient safety, and control the dose of radiology for each patient. Each radiologist has its own set of standard operation process (SOP). Each radiologist must be forced to join the Association of Radiology, to comply with the rules set by the Association. Then, the vision in the radiologist division follows the Association of Radiology, such as a learning goal: to complete 150 learning credits within six years. However, without the set of the common goals, especially applicable to Joseph Hospital, radiologists seem to have higher turnover than nurse anesthetists. The interviews data indicated that "there is no big difference in requirements between here and elsewhere, the only difference is that we have lower amount of work than in city hospitals."

\section{Shared Repertoire}

CoPs develop a shared repertoire of resources: experiences, stories, tools, ways of addressing recurring problems - in short a shared practice (Wenger et al., 2002). In conversation, or sustained interaction, members will apply the knowledge acquired to affect the efficiency and effectiveness in medical work. And a shared practice (repertoire), or to be specifically, the integrated knowledge makes impacts on the way members worked and improved the effectiveness of anesthesia quality. It is critical that the community has a community memory which retains the relevant practice knowledge. During the interactions, CoP members conduct cognitive processes of narration or terms that can help them to effectively interpret a new problem encountered. An interview mentioned by a nurse anesthetist is like the following:

For example, there was a case encountered yesterday, and it had a similar situation with the previous experience which enabled members to be able to learn what should be paid attention. We will use the professional terms to accelerate the involvement in communication with each other; some things may be encapsulated in only two simple words, and everyone would immediately know what is mentioned.

Distributed leadership helps to develop the community memory through facilitating multiple participations in the interactions, especially in informal face-to-face interactions. As one member referred, "party conversation is relatively easy, and it will not make the nerve very tight." The ability of the CoP members to continuously develop and draw on the community memory was affected by the supportive contexts members have. The results reveal that relaxing surrounding feeling, and trust-worthy places are supportive to high level of informal face-to-face interactions. One junior employee said, "For example today I take care of a patient with some conditions; then the senior partner possibly privately telling me better ways of solutions and the tone of the speech is less likely rushing or clashing." On the basis, interactions emerge on many occasions, and distribution leadership emerges from a variety of sources depending on the issue and who has the relevant expertise or creativity (Bolden, 2011).

Regarding sharing experience in Department of Radiology, radiologists are less likely to share personal experiences through writing into text. However, they will explore scientific data on the internet or information seniors left. When encountering a case of deviation, radiologists check the previous case records first, and if there is no record of the cases, second, they will seek seniors. Normally, new knowledge is related operation of a new radiology 
instrument. But the resource of new knowledge is from manufacturers and from the head of radiologists. As mentioned by a radiologist,

When we installed new machines, manufacturers will find someone to teach us how to operate, we will combine the conditions vendors provide and the conditions physician preferred to follow, and then the first who must learn is the head of radiologists. Because we are required to work on shifts, free people go to learn, and those who do not learn can ask the leader to teach.

\section{Conclusions}

Bolden (2011) described distributed leadership: "an increasing awareness of the importance of social relations in the leadership contract, and a realization that no one individual is the ideal leader in all circumstances have given rise to a new school of leadership thought, referred to as informal, emergent, dispersed or distributed leadership". This study reveals a CoP has distributed (shared) leadership has the following benefits: First, shared leadership emphasizes the individual expertise and experience which was brought to the discussion in a supportive informal face-to-face meetings. And shared leadership encourages each member to set up agendas that were related to emergent cases. Second, shared leadership was intriguing to members and this style facilitates members to work together on setting learning system and enable members to translate common goals into individual cognition. Third, shared leadership also induces members to construct their norms and update the community memory in a fast and easy way. Then, the theoretical implication is that leadership style may be the causal factor to a CoP performance effectiveness and the future study can make empirical examination on the causal links. The practical implication for a CoP suggests that shared responsibility of designing a CoP can make greater interactions than a single leadership who has the most power but not necessarily involve in a CoP.

\section{REFERENCES}

[1] BANDURA, A. (2001) Social cognitive theory: an agentic perspective, Annual Review of Psychology, Vol. 52, pp. $1-26$.

[2] Barron, B. (2003). When smart groups fail. The Journal of the Learning Sciences, 12, 307-359.

[3] Bolden, R. (2011) "Distributed Leadership in Organizations: A Review of Theory and Research". International Journal of Management Reviews, Vol. 13 (3), 251-269.

[4] Brown, J. S., and Duguid, P. (1991), Organizational Learning and Communities-of-Practice: Toward A Unified View of Working, Learning, and Innovation, J. S. Brown and P. Duguid, Organization Science, Vol. 2, 40-57.
[5] Brown, J. S., and Duguid, P. (2000), The social life of information. Boston, MA: Harvard Business School Press.

[6] Crook, C. (1998). "Children as computer users: The case of collaborative learning." Computer and Education, 30(3 and 4), 237-247.

[7] Fallah, N. (2011), "Distributed form of leadership in communities of practice", International Journal of Emerging Science, 1(3): 357-370.

[8] Iverson, J. O. and McPhee, R. D. (2008), "Communicating knowing through communities of practice: exploring internal communicative processes and difference among CoPs," Journal of Applied Communication Research, vol. 36 (2), 176-199.

[9] Janesick, V. J. (2000), "The choreography of qualitative research design: Minutes, improvisations, and crystallization," In N. K. Denzin \& Y. S. Lincoln (Eds.), Handbook of qualitative research (2nd ed., pp. 379-399). Thousand Oaks, CA: Sage.

[10] Kogut, B., and Zander, U. (1992), "Knowledge of the firm, combinative capabilities, and the replication of technology," Organ. Sci. 3 (3)383-397.

[11] Lakomski, G. (2008). "Functionally adequate but casually idle: w(h)ither distributed leadership". Journal of Educational Administration., 46 (2), 159-171.

[12] Nonaka, I., Toyama, R. \& Hirata, T. (2000), "SECI, ba and leadership: a unified model of dynamic knowledge creation", Long Range Planning, vol. 33, pp. 5-34.

[13] Orlikowski, W. J. (2002). Knowing in practice. Enacting a collective capability in distributed organization. Organization Science, 13(4), 249-273.

[14] Spender, J.C., and Grant, R. M. (1996), "Knowledge and the firm: Overview," Strategic Management J. 17. (S2), 5-9.

[15] Van den Bossche, P., Gijselaers, W. H., and Segers, M., (2006), "Social and cognitive factors driving teamwork in collaborative learning environment: team learning beliefs and behaviors," Small Group Research, vol. 37 (5), 490-521.

[16] Von Krogh, G., J. Roos, K. Slocum. (1994), “An essay on corporate epistemology”, Strategic Management J. 15 53-71.

[17] Wenger, E. (1998), Communities of Practice: Learning, Meaning, and Identity. Cambridge University Press, Cambridge, UK.

[18] Wenger, E., and Snyder, W. (2000), "Communities of practice: The organizational frontier". Harvard Business Review. 78 (1), 139-145.

[19] Wenger, E., McDermott, R. and Snyder, W. M., (2002), "Cultivating Communities of Practice: A guide to managing knowledge," Boston, MA: Harvard Business School Press.

[20] Winter, S. (1987), Knowledge and competence as strategic assets. D. Teece, ed. The Competitive Challenge-Strategic for Industrial Innovation and Renewal. Ballinger, Cambridge, MA.

[21] Zboralski, K. (2009) "Antecedents of knowledge sharing in communities of practice", Journal of Knowledge Management, Vol. 13( 3), 90 - 101. 